\title{
Impact of Zero Tillage and Tillage Practice in Chickpea Production
}

\author{
Md. Abdul Quddus ${ }^{1}$, Habib Mahammad Naser ${ }^{2}$, Md. Alamgir Siddiky ${ }^{1}$, Md. Razzab Ali ${ }^{3}$, \\ A. T. M. Anwarul Islam Mondol ${ }^{2} \&$ Md. Anarul Islam ${ }^{4}$ \\ ${ }^{1}$ Soil and Water Management Section, Horticulture Research Centre, Bangladesh Agricultural Research Institute, \\ Gazipur, Bangladesh \\ ${ }^{2}$ Soil Science Division, Bangladesh Agricultural Research Institute, Gazipur, Bangladesh \\ ${ }^{3}$ Olericulture Division, Horticulture Research Centre, Bangladesh Agricultural Research Institute, Gazipur, \\ Bangladesh \\ ${ }^{4}$ Pomology Division, Horticulture Research Centre, Bangladesh Agricultural Research Institute, Gazipur, \\ Bangladesh \\ Correspondence: Md. Abdul Quddus, Soil and Water Management Section, Horticulture Research Centre, \\ Bangladesh Agricultural Research Institute, Gazipur, Bangladesh. E-mail: quddus06@yahoo.com
}

Received: December 31, 2019

Accepted: February 2, $2020 \quad$ Online Published: March 15, 2020

doi:10.5539/jas.v12n4p106

URL: https://doi.org/10.5539/jas.v12n4p106

\begin{abstract}
The study was carried out at the field of Regional Pulses Research Station, Madaripur under Bangladesh Agricultural Research Institute (BARI) during Rabi season (winter) to evaluate the effect of different tillage practices on growth, yield attributes, nutrient uptake and yield of chickpea, and to compare between the zero tillage and tillage practice.The experiment was planned with five different tillage practices viz. Zero tillage $\left(T_{1}\right)$, Single tillage $\left(T_{2}\right)$, Two tillage $\left(T_{3}\right)$, Three tillage $\left(T_{4}\right)$ and Four tillage $\left(T_{5}\right)$, and it was laid out in a randomized complete block design (RCBD) with three replications. Blanket dose of fertilizers of $\mathrm{N}, \mathrm{P}, \mathrm{K}, \mathrm{S}, \mathrm{Zn}$ and $\mathrm{B}$ at 20 , $21,30,10,3$ and $1.5 \mathrm{~kg} \mathrm{ha}^{-1}$, respectively were used in all tillage treatments. The highest mean seed yield achieved $\left(1395 \mathrm{~kg} \mathrm{ha}^{-1}\right)$ in zero tillage $\left(T_{1}\right)$ followed by four tillage $\left(T_{5}\right)$ practice. The maximum number of branches plant ${ }^{-1}$ and more number of pods plant ${ }^{-1}$ was recorded in zero tillage treatment. Nutrient content showed non-significant effect across most of the treatment. The highest nodulation and nutrient (N, P, K and S) uptake was also obtained from $T_{1}$ treatment. Tillage practices exhibited positive effects on soil properties. The highest soil organic carbon, total $\mathrm{N}$, available $\mathrm{P}, \mathrm{K}, \mathrm{S}, \mathrm{Ca}, \mathrm{Mg}, \mathrm{Zn}$ and $\mathrm{B}$ were found in zero tillage $\left(\mathrm{T}_{1}\right)$. Based on profitability, the zero tillage was economically viable with compared to tillage practice. Although this practice $\left(\mathrm{T}_{1}\right)$ saves the money about $3.8 \%$ to $13.7 \%$ and time also saves minimum 8 days for succeeding crops. So, the present study suggests that zero tillage practice could be implemented in the high and medium high land for chickpea cultivation. Low income farmers may practice the zero tillage technology. Future research should be carried out to evaluate the suitable rate of nutrient in zero tillage (conservative tillage) practice for yield maximization of chickpea and sustaining soil fertility.
\end{abstract}

Keywords: zero tillage, tillage practice, chickpea yield, yield attributes, nodulation, nutrient uptake

\section{Introduction}

Globally the agriculture has currently been faceing enormous challenges including soil erosion which significantly reduces the yield of crops. The soil erosion by wind and related dust emission can cause substantial nutrient loss and may lead to soil degradation of fertile lands (Katra, 2020). Tillage activities can significantly accelerate wind erosion and soil loss compared with uncultivated soils or zero tillage (Sharratt et al., 2010; Singh et al., 2012). The shortage of water and increasing the price of fuel and fertilizer will increase the production costs. Increasing demand of food for the unprecedented growth of the population in recent decades has created a major challenge for researchers in the agricultural sector (Salehi et al., 2017). Chickpea (Cicer arietinum L.) can increase the productivity both in terms of $\mathrm{N}$ saving from fertilizer sources and build up soil fertility through biological source of $\mathrm{N}$ (Banjara et al., 2017). It can fix $\mathrm{N}$ up to $140 \mathrm{~kg} \mathrm{ha}^{-1}$ in a growing period (Poonia and Pithia, 2013). Tillage methods affect the sustainable resources through its influence on soil properties, crop growth and the use of excessive and un-necessary tillage operations is often harmful to soil (Nazeer et al., 2012). Conservation agriculture (CA) techniques involve zero tillage which reduces the negative environmental effects of agriculture such as soil erosion and degradation of physical properties of soil leading to decrease crop productivity (Monneveux et al., 2006). 
Generally, Bangladesh crop agriculture depicts excessive tillage, crop residue removal and imbalance fertilization that degraded soil health with accelerated decomposition of soil organic matter (SOM) (Salahin et al., 2019). Most agricultural soils have become vulnerable to tillage-stimulated rapid loss of SOM in the coarse texture soils (Stewart et al., 2007). Minimum or zero tillage practice to some extent increases SOM levels (Busari and Salako, 2013), enriches soil nutrients (Alam, 2018), water retention capacity (Aziz et al., 2013), and decreases the cost of production (Salahin, 2017) by reducing fuel use for intensive tillage and irrigation requirements (Johansen et al., 2012). Enormous studies conducted in home and abroad also showed that zero and minimum tillage increases SOM, microbial activity, total N, and extractable $\mathrm{P}, \mathrm{S}, \mathrm{Zn}$ and $\mathrm{B}$ at the soil surface to a large extent compared to conventional tillage (Alam et al., 2016; Vu et al., 2009).

Chickpea is the third most important pulse crop in the world and stands $5^{\text {th }}$ in respect of area $(8250$ ha) and production (6488 tons $\mathrm{yr}^{-1}$ ) in Bangladesh with an average yield of $786 \mathrm{~kg} \mathrm{ha}^{-1}$ (BBS, 2016). It is grown in winter season of Bangladesh and competes with a variety of winter crops. It contains higher level of protein, fiber, minerals (phosphorus, calcium, magnesium, iron and zinc) and $\beta$-carotene (Legesse et al., 2017). The acreage of chickpea cultivation in Bangladesh is decreasing day by day due to disease infestation and less return as compared to some cereal crops (i.e., Boro rice and maize). Hence, the uses of high yielding variety (HYV) of chickpea and proper tillage practice can increase the hectare yield of chickpea. The farmers of Faridpur and Madaripur district, Bangladesh have been cultivating T. Aman rice in medium low lands. These areas stand under the low Ganges river floodplain soils which fertility is low to medium. After T. Aman rice, chickpea can easily be adopted through zero tillage practice (CA practice) in winter season.

Thus, zero tillage along with some complimentary practices has emerged as a viable option to ensure sustainable food production and maintain environmental integrity (Corsi et al., 2012). However, in Bangladesh there are very limited works on zero tillage practices for chickpea cultivation. Considering these issues, an attempt was made to identify the suitable tillage practice to reduce the vagaries of drought on growth, productivity and profitability of chickpea and save time for the successive crops in the same land.

\section{Materials and Methods}

\subsection{Experimental Site Description}

The field experiment was conducted during the Rabi (winter) season of 2012-13 and 2013-14 at Regional Pulses Research Station (RPRS), Madaripur ( $23^{\circ} 10^{\prime} \mathrm{N}$ latitude and $90^{\circ} 11^{\prime} \mathrm{E}$ longitude), BARI at an elevation of $7.0 \mathrm{~m}$ above the sea level. It belongs to the agro ecological zone, Low Ganges River Floodplain (AEZ 12). According to general soil classification, it falls under Calcareous Brown Floodplain Soils with Gopalpur soil series. Beginning the experiment, initial soil sample was collected at $0-15 \mathrm{~cm}$ depth from different spots of the experimental field and analysed. The morphological, taxonomical and physical characteristics are shown in Table 1. The chemical properties are presented in Table 2 .

Table 1. Morphological, taxonomical and physical characteristics of the experimental field

\begin{tabular}{|c|c|c|c|}
\hline Characteristics & RPRS farm, Madaripur & & \\
\hline Agro-Ecological Zone (UNDP, 1988) & Low Ganges River Floodplain (AEZ 12) & & \\
\hline General soil type & Calcareous Brown Floodplain Soil & & \\
\hline Taxonomic soil classification & & Physical properties of soil & Values \\
\hline Order & Inceptisols & $\%$ Sand & 30.72 \\
\hline Sub order & Ochrepts & $\%$ Silt & 44.00 \\
\hline Great group & Eutrochrepts & $\%$ Clay & 25.28 \\
\hline Sub-group & Aquic Eutrochrepts & Textural class & Loam \\
\hline Soil series & Gopalpur & Particle density $\left(\mathrm{g} \mathrm{cm}^{-3}\right)$ & 2.60 \\
\hline Parent material & Gangetic alluvium & Bulk density $\left(\mathrm{g} \mathrm{cm}^{-3}\right)$ & 1.39 \\
\hline Topography & Level & Porosity $(\%)$ & 46.54 \\
\hline Drainage situation & Moderate & Hydraulic conductivity $\left(\mathrm{cm} \mathrm{sec}^{-1}\right)$ & $2.14 \times 10^{-5}$ \\
\hline Flood level & Above flood level & & \\
\hline Geographic position & $\begin{array}{l}23^{\circ} 10^{\prime} \mathrm{N} \text { latitude and } 90^{\circ} 11^{\prime} \mathrm{E} \text { longitude, } \\
7.0 \mathrm{~m} \text { above sea level }\end{array}$ & & \\
\hline Land type & High land & & \\
\hline
\end{tabular}


Table 2. Chemical properties of initial soil of the experimental field

\begin{tabular}{|c|c|c|c|c|c|c|c|c|c|c|c|}
\hline Location & $\mathrm{pH}$ & Previous crop & OC & Total N & $\mathrm{Ca}$ & $\mathrm{Mg}$ & $\mathrm{K}$ & $\mathrm{P}$ & $\mathrm{S}$ & $\mathrm{Zn}$ & $\mathrm{B}$ \\
\hline & & & \multicolumn{2}{|c|}{----- $\mathrm{g} \mathrm{kg}^{-1}$------ } & \multicolumn{3}{|c|}{---- meq. $100 \mathrm{~g}^{-1}$---- } & \multicolumn{4}{|c|}{--o- $\mathrm{mg} \mathrm{kg}^{-1}$} \\
\hline Madaripur (result) & 7.4 & & 8.38 & 0.65 & 13.1 & 5.15 & 0.16 & 16 & 18.3 & 1.10 & 0.16 \\
\hline Critical level & - & T. aman rice & - & 1.2 & 2.0 & 0.50 & 0.12 & 10 & 10 & 0.60 & 0.20 \\
\hline *Interpretation & slightly alkaline & & low & very low & high & high & low & medium & medium & medium & low \\
\hline
\end{tabular}

Note. * Bangladesh Agricultural Research Council (2012).

The climate of the experimental site is sub-tropical humid monsoon condition. It is characterized by comparatively monsoon rainfall, high humidity, and high temperature during March to June. Long day with less clear sunshine, sometimes the sky remains cloudy for heavy rainfall (about $80 \%$ of the total rainfall) during June to October. The scanty rainfall, low humidity, and low temperature, short day and more clear sunshine during October to March. Average temperature ranged from 13.0 to $38{ }^{\circ} \mathrm{C}$ and average annual rainfall varied from 1500 to $5500 \mathrm{~mm}$ around the year (Huq and Shoaib, 2013). The rainfall ganged from 7.6 to $80.2 \mathrm{~mm}$ during the period of the experiment. The mean minimum and maximum air temperature during this period was 10.3 and $34.8^{\circ} \mathrm{C}$, respectively.

\subsection{Experimental Design, Treatment and Layout}

The experiment was laid out in a randomized complete block design (RCBD) with three replicates and consisted of five tillage practices such as $T_{1}$ (Zero tillage-soil was undisturbed, but furrow was prepared by manually made single tine for seed sowing), $T_{2}$ (Single tillage-tilled one pass of power tiller machine followed by 1 laddering), $\mathrm{T}_{3}$ (Two tillage-tilled two passes of power tiller machine followed by 2 laddering), $\mathrm{T}_{4}$ (Three tillage-tilled three passes of power tiller machine followed by 2-3 laddering) and $\mathrm{T}_{5}$ (Four tillage-tilled four passes of power tiller machine followed by 2-3 laddering). The depth range of tillage practices were maintained by 6 to $12 \mathrm{~cm}$. The unit plot size was $5 \mathrm{~m} \times 4 \mathrm{~m}$ with the spacing of $50 \mathrm{~cm} \times 10 \mathrm{~cm}$.

\subsection{Agronomic Management}

In the experiment, the soils for zero tillage was remain undisturbed during the period of rice harvest for sowing chickpea. However, the T. Aman rice was harvested retaining about $15 \mathrm{~cm}$ straw in the study plot. The test crop variety was BARI Chola-9. Chickpea seeds at $40 \mathrm{~kg} \mathrm{ha}^{-1}$ were sown in the plot of zero tillage in furrow continuously about $4-5 \mathrm{~cm}$ depth maintaining row to row distance $50 \mathrm{~cm}$ on 03 November 2012 and 04 November 2013. Fertilizers of N, P, K, S, Zn, and B at 20, 21, 30, 10, 3 and $1.5 \mathrm{~kg} \mathrm{ha}^{-1}$ respectively were applied after one day of rice harvesting in the zero tillage plot. On the other hand, whole amount of fertilizers of N, P, K, $\mathrm{S}, \mathrm{Zn}$ and $\mathrm{B}$ at $20,21,30,10,3$ and $1.5 \mathrm{~kg} \mathrm{ha}^{-1}$ respectively were used in all the plot of tillage treatments. The sources of N, P, K, S, Zn and B, respectively were urea, TSP, MoP, gypsum, zinc sulphate and boric acid. The seed rate of $40 \mathrm{~kg} \mathrm{ha}^{-1}$ was also sown in all tillage plots continously maintaining row to row distance $50 \mathrm{~cm}$ on 13 November 2012 and 14 November 2013. Three hand weedings were completed for zero tillage at 15, 30 and 50 days after sowing. On the other hand, two hand weedings were done for all plots of tillage practices at 25 and 50 days after sowing. The disease (BGM) influx was managed by spraying the fungicide Secure $600 \mathrm{wg}$ at $0.2 \%$ two times at an interval of 10 days start at flowering stage. The insect (pod borer and aphid) infestation was controlled by spraying Karate at $0.2 \%$ two times at 10 day intervals during podding stage. Irrigation was not applied. The test crop was harvested at maturity. Crop of zero tillage was harvested on 4 March 2013 and 3 March 2014 and the crop of tillage practices (single, two, three and four tillage) was harvested on 11 March 2013 and 12 March 2014. Maturity refers that chickpea pods to be brown or yellow brown coloured and seed become hard having 12 to $16 \%$ moisture.

\subsection{Data Collection}

In the experiment, the nodules per plant were counted at 60 days after sowing (DAS) in each treatment plot by selecting 5 plants randomly. The chickpea plants were simply uprooted with the help of Khurpi and the roots were washed carefully by clean water. Then the roots were blotted with tissue paper. The number of nodules per plant was counted and averaged. Mature ten plants of chickpea were randomly selected and uprooted from each treatment plot. Plot wise from these ten plants, the data of plant height, number of branches per plant, pods per plant, respectively were recorded. Plant height was recorded from above ground part and averaged. Primary branches per plant was counted and averaged. Pods were detached from every plant and the number of pods per plant was counted and averaged. Ten pods were separated randomly from composite pods of 10 plants from each plot. The number of seeds per pod was counted from ten pods and averaged. For stover yield $\left(\mathrm{kg} \mathrm{ha}^{-1}\right)$, mature plants were collected instead of border row from $1-\mathrm{m}^{2}$ in each plot at harvest time. The harvested plants were sun dried and seeds were separated. The dry straws were weighed and the weight was converted to $\mathrm{kg} \mathrm{ha}^{-1}$. For seed yied, total dried seed (9\% moisture) of each treatment plot $(5 \mathrm{~m} \times 4 \mathrm{~m})$ was weighed and converted it to $\mathrm{kg} \mathrm{ha}^{-1}$. 
The 100-seed weight (g) was determined by randomly counting of 100 -seed from the whole seeds of each plot and weighed. Percentage of harvest index (HI) was determined by the formula,

$$
\mathrm{HI}=\frac{\text { Economic yield }}{\text { Biological yield }} \times 100
$$

\subsection{Soil Samples Collection, Preparation and Analysis}

Before stating the experiment, soil samples of the experimental area was collected $(0-15 \mathrm{~cm}$ depth) from five spot with auger and mixed together thoroughly to make a composite sample which was brought to the laboratory. It was air dried and ground to pass through 20 mesh sieve. Postharvest soil samples of the experimental plot were collected from $0-15 \mathrm{~cm}$ depth. The combined soil sample of each plot was brought to the laboratory and spread on a brown paper for air drying. The air-dried soil samples were ground and passed through a 20-mesh sieve. After sieving, the prepared soil samples were kept into plastic containers with proper label for physical and chemical analysis.

\subsubsection{Methods of Physical Properties Analysis}

Textural analysis of soils was done by hydrometer method (Bouyoucos, 1962) and the textural class was determined from Marshall's triangular co-ordinate following USDA system. Particle density was determined by volumetric flask method (Black, 1965) using the formula mentioned below.

$$
\text { Particle density }(\mathrm{Dp})=\frac{\mathrm{M}_{\mathrm{s}}}{\mathrm{Vs}_{\mathrm{s}}}\left(\mathrm{g} \mathrm{cm}^{-3}\right)
$$

Where, $D_{\mathrm{P}}=$ Particle density $\left(\mathrm{g} \mathrm{cm}^{-3}\right), \mathrm{Vs}=$ Volume of soil solid $\left(\mathrm{cm}^{-3}\right), \mathrm{Ms}=$ Weight of soil solid $(\mathrm{g})$. Bulk density was determined by core sampler method (Black, 1965) using the following formula.

$$
\text { Bulk density }(\mathrm{Db})=\frac{\mathrm{M}_{\mathrm{s}}}{\mathrm{Vt}}\left(\mathrm{g} \mathrm{cm}^{-3}\right)
$$

Where, $\mathrm{Db}=$ Bulk density $\left(\mathrm{g} \mathrm{cm}^{-3}\right), \mathrm{Ms}=$ Mass of soil solid $(\mathrm{g}), \mathrm{Vt}=$ Total volume of soil $\left(\mathrm{cm}^{-3}\right)$. Soil porosity was calculated from the results of particle density and bulk density with the following formula.

$$
\text { Soil porosity }=\frac{D_{p}-D_{b}}{D_{p}} \times 100
$$

Where, $\mathrm{Dp}=$ Particle density $\left(\mathrm{g} \mathrm{cm}^{-3}\right), \mathrm{Db}=$ Bulk density $\left(\mathrm{g} \mathrm{cm}^{-3}\right)$. Saturated hydraulic conductivity was determined by constant head method (Klute, 1965) from eight experimental sites. Samples were collected from $0-15 \mathrm{~cm}$ depth using core samplers in triplicate. The hydraulic conductivity was calculated by using Darcy's equation as follows:

$$
\mathrm{K}=-\frac{\mathrm{OL}}{\mathrm{AT} \Delta \mathrm{H}}\left(\mathrm{cm} \mathrm{hr}^{-1}\right)
$$

Where, $\mathrm{K}=$ Saturated hydraulic conductivity $\left(\mathrm{cm} \mathrm{hr}^{-1}\right), \mathrm{A}=$ Cross sectional area of the sample in $\mathrm{cm}^{2}, \mathrm{~T}=$ Time in minute, $\mathrm{Q}=$ Quantity of water $(\mathrm{ml})$ passing through the sample in time ' $\mathrm{T}$ ', $\mathrm{L}=$ Length of the sample in $\mathrm{cm}$, $\Delta \mathrm{H}=$ Hydraulic head difference (Length of sample + height of water above the sample) in $\mathrm{cm}$.

\subsubsection{Methods of Chemical Properties Analysis}

Soil $\mathrm{pH}$ was measured by glass electrode $\mathrm{pH}$ meter using soil: water ratio of 1:2.5 Page et al. (1982). Organic carbon was determined following the wet oxidation method as described by Page et al. (1982). Total N content was determined following micro Kjeldhal method (Bremmer and Mulvaney, 1982). Available P by Olsen method as described by Page et al. (1982) and available $\mathrm{S}$ were determined by extracting the soil sample with $0.15 \%$ $\mathrm{CaCl}_{2}$ solution as described by Page et al. (1982). The reading was taken using UV visible Spectrophotometer (Varian Model 50 Conc.) at $720 \mathrm{~nm}$ and $420 \mathrm{~nm}$ wavelength for $\mathrm{P}$ and S, respectively. Exchangeable $\mathrm{K}, \mathrm{Ca}$ and $\mathrm{Mg}$ were extracted with $1 \mathrm{M} \mathrm{NH4OAc}$ solution $(\mathrm{pH}=7$ ) (Thomas, 1982). For exchangeable $\mathrm{K}$, the reading was taken directly using AAS (Chemito AA 203) at $766.5 \mathrm{~nm}$ wavelength. For Ca, $2 \mathrm{ml}$ aliquot was diluted with $1 \mathrm{ml}$ of $\mathrm{La}_{2} \mathrm{O}_{3}$ and $7 \mathrm{ml}$ of distilled water and then reading was taken using AAS (Chemito AA 203). In case of Mg, 1 $\mathrm{ml}$ aliquot was diluted with $9 \mathrm{ml}$ of distilled water and reading was taken using the same AAS. Available $\mathrm{Zn}$ was determined by DTPA method (Lindsay and Norvell, 1978); available B by azomethine-H method Page et al., (1982).

\subsection{Plant Sample Analysis}

Ground straw and seed samples were digested with di-acid mixture $\left(\mathrm{HNO}_{3}-\mathrm{HClO}_{4}\right)(5: 1)$ as described by Piper (1964) for the determination- concentration of N (Micro-Kjeldahl method), P (spectrophotometer method), $\mathrm{K}$ (atomic absorption spectrophotometer method) and $\mathrm{S}$ (turbidity method using $\mathrm{BaCl}_{2}$ by spectrophotometer).

\subsection{Nutrient Uptake Determination}

Nutrient (N, P, K, S, Zn and B) uptake by the test crop was calculated from the results of crop yield and nutrient content in seed and straw (FRG, 2012). 


\subsection{Statistical Analysis}

The experiment was conducted two years following a randomized complete block design (RCBD) with three replications. Analysis of variance was performed following RCB design. The average of two years data of nutrient $(\mathrm{N}, \mathrm{P}, \mathrm{K}$ and $\mathrm{S})$ content and data of nutrient uptake were used for statistical analysis. All data obtained from the experiments were analyzed by statistical software Statistix-10 (Statistix-10, 1985). The means of all data were compared using the least significant difference (LSD) test at a significant level of $\mathrm{p} \leq 0.05$.

\subsection{Partial Budget Analysis}

Benefit cost ratio (BCR) refers to the ratio of gross return and the total variable cost of production of any project in monetary term. Higher BCR expresses higher return from the production and vice-versa. BCR was determined (Tithi and Barmon, 2018) by the formula,

$$
\mathrm{BCR}=\frac{\mathrm{GR}}{\mathrm{VC}}
$$

BCR was counted for a hectare of land. Treatment wise management cost was calculated by adding the cost incurred for labours, ploughing and inputs for each treatment. The seed yield was converted into $\mathrm{kg} \mathrm{ha}^{-1}$. This yield was used to calculate the gross return. The shadow prices of land rent and straw cost were not considerd in this study. The gross return was measured by multiplying the seed yield by the present unit price of chickpea. Gross margin was calculated by subtracting management cost from gross return.

\section{Results and Discussion}

\subsection{Growth and Yield Attributes of Chickpea}

Growth and yield attributes of chickpea showed significant variation due to different tillage practices except 100 -seed weight that was non-significant (Tables 3 and 4$)$. Significantly tallest plant $\left(48.9 \mathrm{~cm}\right.$ in $1^{\text {st }}$ year and $50.1 \mathrm{~cm}$ in $2^{\text {nd }}$ year) was observed in zero tillage $\left(\mathrm{T}_{1}\right)$ treatment as compared to the rest of treatments, however, it was found statistically similar to treatment $T_{5}$ in both the years but at par $T_{3}$ at $1^{\text {st }}$ year and $T_{4}$ at $2^{\text {nd }}$ year. The mean plant height of chickpea varied from 42.2 to $49.5 \mathrm{~cm}$ across the treatments, while the dwarf plant $(42.2 \mathrm{~cm})$ was recorded from $T_{2}$ treatment (Table 3). The tallest plant in $T_{1}$ treatment might be indicated as keeping optimum moisture in soil for available nutrients to plant uptake. This observation is partially in agreement with the findings of Banjara et al. (2017) who reported that zero tillage and minimum tillage both were showed statistically similar result on plant height of chickpea. The maximum number of branches per plant $\left(4.78\right.$ at $1^{\text {st }}$ year and 4.29 at $2^{\text {nd }}$ year) was obtained by zero tillage $\left(T_{1}\right)$ followed by four tillage practice $\left(T_{5}\right)$ and the minimum branches per plant were obtained from single tillage $\left(\mathrm{T}_{2}\right)$ treatment. The mean (average of two years) branches per plant were ranged from 3.65 to 4.54 across the treatments (Table 3). Soil physical properties were might be more favourable in zero tillage than tillage-based systems. It was found that zero tillage significantly improved saturated and unsaturated hydraulic conductivity owing to either continuity of pores or flow of water through very few large pores (Lal, 1997; Allmaras et al., 1977; Benjamin, 1993). However, zero tillage contributed to get higher number of branches plant ${ }^{-1}$. In this experiment, the highest number of pods per plant (56.6 at $1^{\text {st }}$ year and 57.2 at $2^{\text {nd }}$ year) was recorded from the treatment $T_{1}$ which was showed significant different to other treatments, but statistically identical to $\mathrm{T}_{5}, \mathrm{~T}_{4}$ and $\mathrm{T}_{3}$ treatments. The mean number of pods per plant was varied among the treatments from 49.9 to 56.9 , while the highest pods per plant was attained in zero tillage $\left(\mathrm{T}_{1}\right)$ and lowest was in single tillage $\left(\mathrm{T}_{2}\right)$ (Table 3). Number of pods per plant is most prominent yield trait and, is much closed to obtain higher yield. The highest number of pods plant ${ }^{-1}$ was achieved in zero tillage $\left(T_{1}\right)$ which is related with more branching. The climatic condition of zero tillage plots might be favoured to growth and development of chickpea plant. Busari et al. (2015) reported that zero (no-till) tillage system successfully adopts the weather conditions in the growing season. According to an FAO (2012) report, climate adaptation benefits of no-tillage can be significant. As a result, the higher number of pods per plant was acquired in zero tillage than tillage practice. 
Table 3. Effect of different tillage practices on plant height, number of branches plant ${ }^{-1}$ and number of pods plant $^{-1}$ of chickpea

\begin{tabular}{|c|c|c|c|c|c|c|c|c|c|}
\hline \multirow{2}{*}{ Treatment } & \multicolumn{3}{|c|}{ Plant height $(\mathrm{cm})$} & \multicolumn{3}{|c|}{ No. of branches plant $^{-1}$} & \multicolumn{3}{|c|}{ No. of pods plant ${ }^{-1}$} \\
\hline & 1 st yr. & 2nd yr. & Mean & 1st yr. & 2nd yr. & Mean & 1st yr. & 2nd yr. & Mean \\
\hline $\mathrm{T}_{1}$ (Zero tillage) & $48.9 \mathrm{a}$ & $50.1 \mathrm{a}$ & 49.5 & $4.78 \mathrm{a}$ & $4.29 \mathrm{a}$ & 4.54 & $56.6 \mathrm{a}$ & $57.2 \mathrm{a}$ & 56.9 \\
\hline $\mathrm{T}_{2}$ (Single tillage) & $42.6 \mathrm{c}$ & $41.8 \mathrm{~b}$ & 42.2 & $3.52 b$ & $3.77 \mathrm{~b}$ & 3.65 & $50.1 \mathrm{~b}$ & $49.7 b$ & 49.9 \\
\hline $\mathrm{T}_{3}$ (Two tillage) & $46.7 \mathrm{ab}$ & $43.6 b$ & 45.2 & $4.12 \mathrm{ab}$ & $3.93 b$ & 4.03 & $53.9 \mathrm{ab}$ & $54.6 \mathrm{a}$ & 53.7 \\
\hline $\mathrm{T}_{4}$ (Three tillage) & $44.3 \mathrm{bc}$ & $47.9 \mathrm{a}$ & 46.1 & $3.97 \mathrm{ab}$ & $3.80 \mathrm{~b}$ & 3.89 & $52.8 \mathrm{ab}$ & $53.5 \mathrm{ab}$ & 53.2 \\
\hline $\mathrm{T}_{5}$ (Four tillage) & $47.4 \mathrm{a}$ & $48.6 \mathrm{a}$ & 48.0 & $4.38 \mathrm{ab}$ & $4.25 \mathrm{a}$ & 4.32 & $54.8 \mathrm{a}$ & $56.3 \mathrm{a}$ & 55.6 \\
\hline $\mathrm{CV}(\%)$ & 3.55 & 3.74 & - & 13.1 & 3.85 & - & 4.07 & 3.95 & - \\
\hline $\mathrm{LSD}_{0.05}$ & 3.07 & 3.27 & - & 1.03 & 0.29 & - & 4.11 & 4.04 & - \\
\hline
\end{tabular}

Note. In a column, the values having common letter do not differ significantly $(\mathrm{P} \leq 0.05)$.

In the case of number of seeds pod $^{-1}$, the maximum number of seeds per pod of chickpea ( 1.35 at $1^{\text {st }}$ year and 1.39 at $2^{\text {nd }}$ year) was recorded significantly from zero tillage $\left(T_{1}\right)$ followed by four tillage treatment $\left(T_{5}\right)$. The mean number of seeds per pod was ranged from 1.24 to 1.37 across the treatments however; the maximum seeds $\operatorname{pod}^{-1}(1.37)$ was found in $T_{1}$ and minimum (1.24) was in single tillage $\left(T_{2}\right)$ treatment (Table 4). Banjara et al. (2017) also reported that the highest number of seeds per pod (1.27) was oberved in both zero tillage and minimum tillage practice. The seed weight of chickpea was exhibited non-significant across the treatments in both the study years. It is noted that seed weight is a vital quality attribute of any crop. But this character might be genetically controlled in same variety; hence the growing condition is not significantly influenced on its expression. In this experiment, the mean 100-seed weight varied from 19.3 to $20.4 \mathrm{~g}$ across the tillage practices, where the highest 100 -seed weight $(20.4 \mathrm{~g})$ was obtained from the $\mathrm{T}_{1}$ treatment and the lowest $(19.3 \mathrm{~g})$ was from $\mathrm{T}_{2}$ treatment (Table 4). The nodulation of chickpea was significantly influenced by different tillage practices (Table 4). The pooled number of nodules per plant was varied from 18.0 to 22.1 across the treatments. The highest number of root nodules plant ${ }^{-1}\left(21.6\right.$ at $1^{\text {st }}$ year and 22.6 at $2^{\text {nd }}$ year $)$ was obtained from zero tillage $\left(\mathrm{T}_{1}\right)$ which was significantly different over the other treatment but statistically identical with $\mathrm{T}_{5}$ treatment in both the years. The lowest (18.0) nodulation (pooled data) of chickpea was found in single tillage $\left(\mathrm{T}_{2}\right)$ practice (Table 4). The prominent result of nodulation by zero tillage might be conserved moisture; improved fertility associated with minimum disturbance of soil and makes more efficient use of natural resources as well as nutrient (FAO, 2001; Bell et al., 2019). Hence, the zero tillage contributed to achieve higher root nodules.

Table 4. Effect of different tillage practices on number of seeds pod ${ }^{-1}$, 100-seed weight and number of nodules plant $^{-1}$ of chickpea

\begin{tabular}{|c|c|c|c|c|c|c|c|c|c|}
\hline \multirow{2}{*}{ Treatment } & \multicolumn{3}{|c|}{ No. of seeds pod ${ }^{-1}$} & \multicolumn{3}{|c|}{ 100-seed weight $(\mathrm{g})$} & \multicolumn{3}{|c|}{ No. of nodules plant ${ }^{-1}$} \\
\hline & 1 st yr. & 2nd yr. & Mean & 1st yr. & 2nd yr. & Mean & 1 st yr. & 2nd yr. & Mean \\
\hline $\mathrm{T}_{1}$ (Zero tillage) & $1.35 \mathrm{a}$ & $1.39 \mathrm{a}$ & 1.37 & $19.7 \mathrm{a}$ & $21.1 \mathrm{a}$ & 20.4 & $21.6 \mathrm{a}$ & $22.6 a$ & 22.1 \\
\hline $\mathrm{T}_{2}$ (Single tillage) & $1.22 \mathrm{~b}$ & $1.26 \mathrm{bc}$ & 1.24 & $18.5 \mathrm{a}$ & $20.0 \mathrm{a}$ & 19.3 & $17.3 b$ & $18.7 \mathrm{bc}$ & 18.0 \\
\hline $\mathrm{T}_{3}$ (Two tillage) & $1.30 \mathrm{ab}$ & $1.22 \mathrm{c}$ & 1.26 & $19.0 \mathrm{a}$ & $20.4 \mathrm{a}$ & 19.7 & $18.3 b$ & $17.9 \mathrm{c}$ & 18.1 \\
\hline $\mathrm{T}_{4}$ (Three tillage) & $1.31 \mathrm{ab}$ & $1.30 \mathrm{~b}$ & 1.31 & $18.9 \mathrm{a}$ & $20.7 \mathrm{a}$ & 19.8 & $17.4 b$ & $19.4 \mathrm{bc}$ & 18.4 \\
\hline $\mathrm{T}_{5}$ (Four tillage) & $1.33 \mathrm{ab}$ & $1.36 \mathrm{a}$ & 1.35 & $19.2 \mathrm{a}$ & $20.9 \mathrm{a}$ & 20.1 & $19.8 \mathrm{ab}$ & $21.3 \mathrm{ab}$ & 20.6 \\
\hline CV $(\%)$ & 5.01 & 2.40 & - & 4.16 & 4.18 & - & 7.82 & 7.48 & - \\
\hline $\mathrm{LSD}_{0.05}$ & 0.12 & 0.06 & - & ns & ns & - & 2.78 & 2.81 & - \\
\hline
\end{tabular}

Note. In a column, the values having common letter do not differ significantly $(\mathrm{P} \leq 0.05)$.

\subsection{Yields of Chickpea}

The chickpea seed yield was significantly influenced $(P \leq 0.05)$ by different tillage practices in both the years. The highest seed yield $\left(1355 \mathrm{~kg} \mathrm{ha}^{-1}\right.$ at $1^{\text {st }}$ year and $1434 \mathrm{~kg} \mathrm{ha}^{-1}$ at $2^{\text {nd }}$ year) was found in zero tillage $\left(\mathrm{T}_{1}\right)$ followed by four tillage $\left(T_{5}\right)\left(1224 \mathrm{~kg} \mathrm{ha}^{-1}\right.$ at $1^{\text {st }}$ year and $1269 \mathrm{~kg} \mathrm{ha}^{-1}$ at $2^{\text {nd }}$ year$)$. The lowest seed yield was obtained in single tillage $\left(\mathrm{T}_{2}\right)$ in both the years which was significantly inferior to another tillage practices. The mean seed yield of chickpea was ranged from 906 to $1395 \mathrm{~kg} \mathrm{ha}^{-1}$ across the treatments (Table 5). In the study, significantly highest straw yield of chickpea in both the years was obtained from $T_{1}$ treatment. Hence, the mean straw yield of chickpea varied from 1577 to $2098 \mathrm{~kg} \mathrm{ha}^{-1}$ across the different tillage practices, while the highest straw yield $\left(2098 \mathrm{~kg} \mathrm{ha}^{-1}\right)$ was recorded from $\mathrm{T}_{1}$ treatment (Table 5). The higher yields of chickpea might be achieved by the more number of branches plant ${ }^{-1}$ and more number of pods plant ${ }^{-1}$. Similar observation was noted by Banjara et al. (2017). Bimbraw (2016) reported that chickpea showed better performance in the zero 
tillage and minimum tillage by placing the seed at proper depth and soil moisture, which resulted in better yield in chickpea. Zero tillage plays a significant role in root mass density distribution in the soil. However, deep tillage obstructed root proliferation by the dense or compact layer of the soil profile (Hassan et al., 2005) which ultimately reduced the yield of chickpea. Bandyopadhyay (2012) observed that root diameter and root mass density of lentil in zero tillage system is increased compared to conventional tillage. Zero tillage might be facilitated to increase organic matter and microbial activities in soil whatever improvement of chickpea yields. Similar opinion made by Peigné et al. (2007) that zero tillage (ZT) practice enhanced microbial activity and C sequestration, reduce nutrient leaching and erosion. Alam et al. (2014) reported that zero tillage significantly increased the soil organic matter in $0-25 \mathrm{~cm}$ soil layer compared to deep tillage. In the present study, the harvest index (HI) exhibited significant variation across the different tillage practices during $1^{\text {st }}$ year and $2^{\text {nd }}$ year (Table 5). The highest harvest index $\left(39.9 \%\right.$ at $1^{\text {st }}$ year and $40.0 \%$ at $2^{\text {nd }}$ year) was recorded from zero tillage $\left(\mathrm{T}_{1}\right)$ which was significantly different over the other treatment but statistically alike with $T_{3}, T_{4} \& T_{5}$ treatments at $1^{\text {st }}$ year and alike with $\mathrm{T}_{4} \& \mathrm{~T}_{5}$ treatments in $2^{\text {nd }}$ year. The mean harvest index data among the different tillage practices were varied from 36.4 to $40.0 \%$ however, the highest $\mathrm{HI} \%$ was found in $\mathrm{T}_{1}$ followed by $\mathrm{T}_{4}$ treatment and the lowest (36.4\%) HI was achieved in $\mathrm{T}_{2}$ treatment (Table 5). Similar result was noted by Banjara et al. (2017) that the highest harvest index $(39.70 \%)$ of chickpea was recorded in zero tillage.

Table 5. Effect of different tillage practices on seed yield, straw yield and harvest index of chickpea

\begin{tabular}{|c|c|c|c|c|c|c|c|c|c|}
\hline \multirow{2}{*}{ Treatment } & \multicolumn{3}{|c|}{ Seed yield $\left(\mathrm{kg} \mathrm{ha}^{-1}\right)$} & \multicolumn{3}{|c|}{ Straw yield $\left(\mathrm{kg} \mathrm{ha}^{-1}\right)$} & \multicolumn{3}{|c|}{ Harvest index (\%) } \\
\hline & 1 st yr. & 2nd yr. & Mean & 1 st yr. & 2nd yr. & Mean & 1st yr. & 2nd yr. & Mean \\
\hline $\mathrm{T}_{1}$ (Zero tillage) & $1355 \mathrm{a}$ & $1434 a$ & 1395 & $2049 a$ & $2147 a$ & 2098 & $39.9 a$ & $40.0 \mathrm{a}$ & 40.0 \\
\hline $\mathrm{T}_{2}$ (Single tillage) & $956 \mathrm{c}$ & $855 \mathrm{c}$ & 906 & $1612 b$ & $1542 \mathrm{c}$ & 1577 & $37.1 \mathrm{~b}$ & $35.6 \mathrm{c}$ & 36.4 \\
\hline $\mathrm{T}_{3}$ (Two tillage) & $1156 \mathrm{abc}$ & $1017 \mathrm{bc}$ & 1087 & $1800 \mathrm{ab}$ & $1688 \mathrm{bc}$ & 1744 & $39.0 \mathrm{ab}$ & $37.6 b$ & 38.3 \\
\hline $\mathrm{T}_{4}$ (Three tillage) & $1103 b c$ & $1200 \mathrm{ab}$ & 1152 & $1788 \mathrm{ab}$ & $1814 \mathrm{abc}$ & 1801 & $38.2 \mathrm{ab}$ & $39.9 a$ & 39.1 \\
\hline $\mathrm{T}_{5}$ (Four tillage) & $1224 \mathrm{ab}$ & $1269 a$ & 1247 & $1987 \mathrm{ab}$ & $2025 \mathrm{ab}$ & 2006 & $38.2 \mathrm{ab}$ & $38.6 \mathrm{ab}$ & 38.4 \\
\hline CV $(\%)$ & 10.1 & 10.9 & - & 11.7 & 10.2 & - & 2.73 & 2.13 & - \\
\hline $\mathrm{LSD}_{0.05}$ & 219 & 239 & - & 407 & 355 & - & 1.97 & 1.54 & - \\
\hline
\end{tabular}

Note. In a column, the values having common letter do not differ significantly $(\mathrm{P} \leq 0.05)$.

\subsection{Effects of Tillage Practices on N, P, K and S Content of Chickpea}

In the present experiment, different tillage practices had no significant contribution to the $\mathrm{N}$ and $\mathrm{S}$ content in seed of chickpea, but showed significant influence to $\mathrm{P}$ and $\mathrm{K}$ content. The results of $\mathrm{P}, \mathrm{K}$ and $\mathrm{S}$ content in straw of chickpea were affected non-significantly by the different tillage practices. On the other hand, $\mathrm{N}$ content in straw was displayed significantly different due to tillage practices (Table 6). The highest $\mathrm{N}$ content in seed (33.9 $\left.\mathrm{g} \mathrm{kg}^{-1}\right)$ was obtained from the $\mathrm{T}_{1}$ treatment; however the lowest $\mathrm{N}\left(32.3 \mathrm{~g} \mathrm{~kg}^{-1}\right)$ content was noted in $\mathrm{T}_{4}$ treatment. In the case of $\mathrm{N}$ content in straw, the highest $\mathrm{N}$ content $\left(16.9 \mathrm{~g} \mathrm{~kg}^{-1}\right)$ was recorded from $\mathrm{T}_{4}$ treatment which was statistically similar to $T_{5}, T_{3}$ and $T_{1}$ treatments (Tables 6). In the study, the highest $P$ content $\left(6.53 \mathrm{~g} \mathrm{~kg}^{-1}\right)$ in seed of chickpea was achieved in the $T_{3}$ treatment, which was statistically comparable with $T_{5}, T_{4}$ and $T_{1}$ treatments and the lowest $\mathrm{P}$ content $\left(5.58 \mathrm{~g} \mathrm{~kg}^{-1}\right)$ was found in $\mathrm{T}_{2}$ treatment. Concerning $\mathrm{K}$ content, the highest $\mathrm{K}$ content in seed of chickpea $\left(16.4 \mathrm{~g} \mathrm{~kg}^{-1}\right)$ was recorded from $\mathrm{T}_{5}$ treatment which was statistically at par with $\mathrm{T}_{4}, \mathrm{~T}_{3}$ and $\mathrm{T}_{1}$ treatments and the lowest $\mathrm{K}$ content $\left(15.2 \mathrm{~g} \mathrm{~kg}^{-1}\right)$ was in $\mathrm{T}_{2}$ treatment. The $\mathrm{K}$ content in straw of chickpea was showed non-sgnificant across the different tillage practices. The highest amount of $\mathrm{S}\left(0.99 \mathrm{~g} \mathrm{~kg}^{-1}\right)$ in seed was got from $T_{4}$ treatment and the highest $S$ content $\left(1.29 \mathrm{~g} \mathrm{~kg}^{-1}\right)$ in straw was obtained from $T_{1}$ treatment, both were not statistically similar to any other treatment (Table 6). Hargrove (1985) reported that the nutrient status in plants which grown under no-tillage management was superior to those grown by conventional tillage. 
Table 6. Effect of different tillage practices on nutrients content in seed and straw of chickpea (pooled data of two years)

\begin{tabular}{|c|c|c|c|c|}
\hline Treatment & $\mathrm{N}$ & $\mathrm{P}$ & $\mathrm{K}$ & $\mathrm{S}$ \\
\hline & \multicolumn{4}{|c|}{ 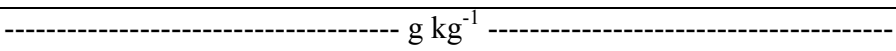 } \\
\hline \multicolumn{5}{|l|}{ Seed } \\
\hline $\mathrm{T}_{1}$ (Zero tillage) & $33.9 \mathrm{a}$ & $5.67 \mathrm{ab}$ & $15.9 \mathrm{ab}$ & $0.97 \mathrm{a}$ \\
\hline $\mathrm{T}_{2}$ (Single tillage) & $33.3 \mathrm{a}$ & $5.58 \mathrm{~b}$ & $15.2 \mathrm{~b}$ & $0.93 \mathrm{a}$ \\
\hline $\mathrm{T}_{3}$ (Two tillage) & $32.4 \mathrm{a}$ & $6.53 a$ & $15.7 \mathrm{ab}$ & $0.98 \mathrm{a}$ \\
\hline $\mathrm{T}_{4}$ (Three tillage) & $32.3 \mathrm{a}$ & $6.50 \mathrm{ab}$ & $16.0 \mathrm{ab}$ & $0.99 \mathrm{a}$ \\
\hline $\mathrm{T}_{5}$ (Four tillage) & $33.8 \mathrm{a}$ & $6.21 \mathrm{ab}$ & $16.4 \mathrm{a}$ & $0.96 \mathrm{a}$ \\
\hline $\mathrm{CV}(\%)$ & 4.55 & 8.23 & 4.84 & 4.87 \\
\hline $\mathrm{LSD}_{0.05}$ & ns & 0.94 & 1.44 & ns \\
\hline \multicolumn{5}{|l|}{ Straw } \\
\hline $\mathrm{T}_{1}$ (Zero tillage) & $16.3 \mathrm{ab}$ & $1.78 \mathrm{a}$ & $25.6 \mathrm{a}$ & $1.29 \mathrm{a}$ \\
\hline $\mathrm{T}_{2}$ (Single tillage) & $15.8 \mathrm{~b}$ & $1.73 \mathrm{a}$ & $24.9 \mathrm{a}$ & $1.26 \mathrm{a}$ \\
\hline $\mathrm{T}_{3}$ (Two tillage) & $16.6 \mathrm{ab}$ & $1.74 \mathrm{a}$ & $25.0 \mathrm{a}$ & $1.18 \mathrm{a}$ \\
\hline $\mathrm{T}_{4}$ (Three tillage) & $16.9 \mathrm{a}$ & $1.80 \mathrm{a}$ & $25.5 \mathrm{a}$ & $1.28 \mathrm{a}$ \\
\hline $\mathrm{T}_{5}$ (Four tillage) & $16.6 \mathrm{ab}$ & $1.79 \mathrm{a}$ & $25.6 \mathrm{a}$ & $1.26 \mathrm{a}$ \\
\hline $\mathrm{CV}(\%)$ & 2.74 & 3.84 & 4.74 & 4.64 \\
\hline $\mathrm{LSD}_{0.05}$ & 0.85 & ns & ns & ns \\
\hline
\end{tabular}

Note. In a column, the values having common letter do not differ significantly $(\mathrm{P} \leq 0.05)$.

\subsection{Effects of Tillage Practices on N, P, K and S Uptake by Chickpea}

The uptake of N, P, K and S by chickpea seed was remarkably influenced by different tillage practices (Tables 7). The uptake of nutrients by seed of chickpea was ranged from 30.1 to $47.3 \mathrm{~kg} \mathrm{~N} \mathrm{ha}^{-1}, 5.06$ to $7.90 \mathrm{~kg} \mathrm{P}^{-1}, 13.8$ to $22.2 \mathrm{~kg} \mathrm{~K} \mathrm{ha}^{-1}$ and 0.84 to $1.35 \mathrm{~kg} \mathrm{~S} \mathrm{ha}^{-1}$ across the treatments. The highest uptake of $\mathrm{N}\left(47.3 \mathrm{~kg} \mathrm{ha}^{-1}\right) \mathrm{was}$ recorded from the $\mathrm{T}_{1}$ treatment which was significantly different with other treatments and the lowest uptake of $\mathrm{N}\left(30.1 \mathrm{~kg} \mathrm{ha}^{-1}\right)$ was observed in $\mathrm{T}_{2}$ treatment. In this study, the highest uptake of $\mathrm{P}\left(7.90 \mathrm{~kg} \mathrm{ha}^{-1}\right)$ by seed was noted in $\mathrm{T}_{1}$ treatment that was statistically similar to the treatments of $\mathrm{T}_{5}, \mathrm{~T}_{4}$ and $\mathrm{T}_{3}$, however the lowest uptake of $\mathrm{P}$ was found in $\mathrm{T}_{2}$ treatment. In the case of $\mathrm{K}$ and $\mathrm{S}$ uptake, the highest uptake of $\mathrm{K}\left(22.2 \mathrm{~kg} \mathrm{ha}^{-1}\right)$ and $\mathrm{S}(1.35$ $\mathrm{kg} \mathrm{ha}^{-1}$ ) was obtained from the $\mathrm{T}_{1}$ treatment (Table 7). Different tillage practices showed significant effect on the uptake of N, P, K and S by chickpea straw (Table 7). In this experiment, the highest uptake of $\mathrm{N}\left(33.4 \mathrm{~kg} \mathrm{ha}^{-1}\right)$ was occurred in the $T_{5}$ treatment which was significantly different over the other treatments, but statistically identical with $T_{1}$ and $T_{4}$ treatments, while the lowest uptake of $\mathrm{N}$ amount $\left(24.9 \mathrm{~kg} \mathrm{ha}^{-1}\right)$ was found in $\mathrm{T}_{2}$ treatment. Regarding $\mathrm{P}$ uptake by straw of chickpea, the uptake of $\mathrm{P}$ was ranged from 2.72 to $3.59 \mathrm{~kg} \mathrm{ha}^{-1}$ across the treatment. The uptake of $\mathrm{P}$ by straw is showed similar trend to the $\mathrm{N}$ uptake by straw. In the case of $\mathrm{K}$ and $\mathrm{S}$ uptake by straw, the maximum uptake of $\mathrm{K}\left(53.6 \mathrm{~kg} \mathrm{ha}^{-1}\right)$ and $\mathrm{S}\left(2.71 \mathrm{~kg} \mathrm{ha}^{-1}\right)$ was recorded from the $\mathrm{T}_{1}$ treatment which treatment was significantly different with other treatment but statistically at par $\mathrm{T}_{5}$ treatment, however the lowest uptake of $\mathrm{K}\left(39.3 \mathrm{~kg} \mathrm{ha}^{-1}\right)$ and $\mathrm{S}\left(1.99 \mathrm{~kg} \mathrm{ha}^{-1}\right)$ was noted in $\mathrm{T}_{2}$ treatment (Table 7). Roy et al. (2014) reported that chickpea sown without seed bed preparation with Pantnagar zero till drill showed the highest NPK uptake as compared to other methods. 
Table 7. Effect of different tillage practices on nutrients uptake by chickpea (Pooled data of two years)

\begin{tabular}{lllll}
\hline Treatment & $\mathrm{N}$ & $\mathrm{P}$ & $\mathrm{K}$ & $\mathrm{S}$ \\
\hline & $\mathrm{kg} \mathrm{ha} \mathrm{h}^{-1}$ & & & \\
Seed & & & & \\
$\mathrm{T}_{1}$ (Zero tillage) & $47.3 \mathrm{a}$ & $7.90 \mathrm{a}$ & $22.2 \mathrm{a}$ & $1.35 \mathrm{a}$ \\
$\mathrm{T}_{2}$ (Single tillage) & $30.1 \mathrm{~d}$ & $5.06 \mathrm{~b}$ & $13.8 \mathrm{c}$ & $0.84 \mathrm{~d}$ \\
$\mathrm{~T}_{3}$ (Two tillage) & $35.2 \mathrm{c}$ & $7.10 \mathrm{a}$ & $17.1 \mathrm{~b}$ & $1.07 \mathrm{c}$ \\
$\mathrm{T}_{4}$ (Three tillage) & $37.2 \mathrm{c}$ & $7.49 \mathrm{a}$ & $18.5 \mathrm{~b}$ & $1.14 \mathrm{bc}$ \\
$\mathrm{T}_{5}$ (Four tillage) & $42.1 \mathrm{~b}$ & $7.74 \mathrm{a}$ & $20.5 \mathrm{a}$ & $1.20 \mathrm{~b}$ \\
\hdashline $\mathrm{CV}(\%)$ & 2.81 & 8.96 & 5.45 & 4.12 \\
$\mathrm{LSD}$ & 2.03 & 1.19 & 1.89 & 0.09 \\
\hline Straw & & & & \\
$\mathrm{T}_{1}$ (Zero tillage) & $31.4 \mathrm{ab}$ & $3.42 \mathrm{ab}$ & $53.6 \mathrm{a}$ & $2.71 \mathrm{a}$ \\
$\mathrm{T}_{2}$ (Single tillage) & $24.9 \mathrm{c}$ & $2.72 \mathrm{c}$ & $39.3 \mathrm{c}$ & $1.99 \mathrm{~d}$ \\
$\mathrm{~T}_{3}$ (Two tillage) & $28.9 \mathrm{bc}$ & $3.04 \mathrm{bc}$ & $43.6 \mathrm{~b}$ & $2.07 \mathrm{~cd}$ \\
$\mathrm{~T}_{4}$ (Three tillage) & $30.5 \mathrm{ab}$ & $3.24 \mathrm{ab}$ & $45.8 \mathrm{~b}$ & $2.30 \mathrm{bc}$ \\
$\mathrm{T}_{5}$ (Four tillage) & $33.4 \mathrm{a}$ & $3.59 \mathrm{a}$ & $51.1 \mathrm{a}$ & $2.52 \mathrm{ab}$ \\
\hline CV (\%) & 7.59 & 8.03 & 4.85 & 5.61 \\
LSD $_{0.05}$ & 4.26 & 0.48 & 4.27 & 0.24 \\
\hline
\end{tabular}

Note. In a column, the values having common letter do not differ significantly $(\mathrm{P} \leq 0.05)$.

In this study, the highest total uptake of $\mathrm{N}\left(78.7 \mathrm{~kg} \mathrm{ha}^{-1}\right)$ by chickpea (seed + straw) was achieved in $\mathrm{T}_{1}$ treatment and the lowest $\left(55.0 \mathrm{~kg} \mathrm{ha}^{-1}\right.$ ) was in $\mathrm{T}_{2}$ treatment (Figure 2). In the case of P uptake, the maximum total P uptake was recorded (11.3 $\mathrm{kg} \mathrm{P} \mathrm{ha}^{-1}$ ) from the treatments $\mathrm{T}_{1}$ and $\mathrm{T}_{5}$ (Figure 2). Regarding $\mathrm{K}$ and $\mathrm{S}$ uptake, the highest total $\mathrm{K}$ uptake was obtained $\left(75.8 \mathrm{~kg} \mathrm{~K} \mathrm{ha}^{-1}\right)$ from the treatments $\mathrm{T}_{1}$ and the highest total $\mathrm{S}$ uptake $\left(4.06 \mathrm{~kg} \mathrm{ha}^{-1}\right)$ was also obtained from the same treatment (Figure 2). The above N, P, K and S uptake variation among the different tillage practices migh be governed by the chickpea yield.

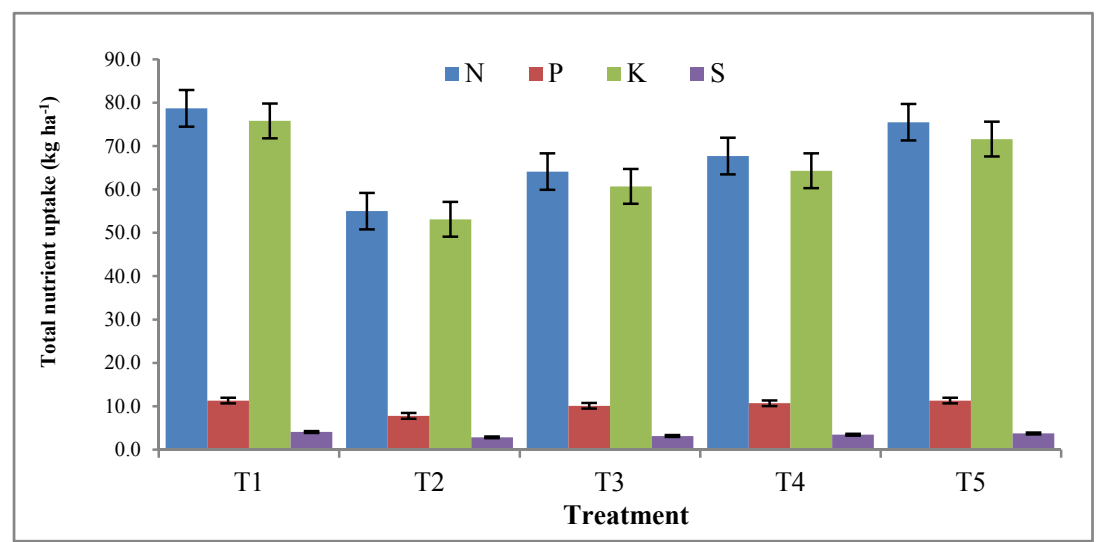

Figure 2. Effect of different tillage practices on total nutrients uptake by chickpea (seed + straw)

Note. $\mathrm{T}_{1}$ (Zero tillage), $\mathrm{T}_{2}$ (Single tillage), $\mathrm{T}_{3}$ (Two tillage), $\mathrm{T}_{4}$ (Three tillage) and $\mathrm{T}_{5}$ (Four tillage). Error bars represent the SEM.

\subsection{Effect of Different Tillage Practices on Postharvest Soil Properties}

Different tillage practices contributed positive impact on postharvest soil properties. In the experiment, the $\mathrm{pH}$ of postharvest soils decreased slightly in all the tillage practices as compared to the initial value (Table 8 ). The $\mathrm{pH}$ of postharvest soil showed significant variation across the treatments. The decreasing percentage value of $\mathrm{pH}$ was highest $(2.70 \%)$ in zero tillage $\left(\mathrm{T}_{1}\right)$ followed by the four tillage $\left(\mathrm{T}_{5}\right)$ and the lowest decrease of $\mathrm{pH}(1.35 \%)$ were observed in others treatments as compared to initial $\mathrm{pH}$ value. The organic carbon (OC) of intial soil was $8.38 \mathrm{~g} \mathrm{~kg}^{-1}$; however tillage practices were exhibited significant change in postharvest soil (Table 8). The highest OC $\left(8.90 \mathrm{~g} \mathrm{~kg}^{-1}\right)$ was recorded from zero tillage $\left(\mathrm{T}_{1}\right)$ which was significantly different with the other treatment, but statistically identical with four tillages $\left(\mathrm{T}_{5}\right)$ and the lowest was in single tillage $\left(\mathrm{T}_{2}\right)$. Bhattacharryya et al. (2008) noted that conservation tillage (zero tillage) system generally improve the soil organic C (SOC). Different tillage practices have a tendency to maintain the initial fertility or increased slightly of soil organic carbon, total 
$\mathrm{N}$, available $\mathrm{P}, \mathrm{S}, \mathrm{Zn}$ and $\mathrm{B}$ except exchangeable $\mathrm{K}, \mathrm{Ca}$ and $\mathrm{Mg}$ that's were static or slightly decreased. In this study, most of the nutrient showed significantly variation among the tillage practices. The significantly highest $\mathrm{N}$ $\left(0.75 \mathrm{~g} \mathrm{~kg}^{-1}\right)$ in soil was found for zero tillage $\left(\mathrm{T}_{1}\right)$ and lowest $\left(0.70 \mathrm{~g} \mathrm{~kg}^{-1}\right)$ was in single tillage $\left(\mathrm{T}_{2}\right)$. Alam et al. (2014) reported that organic matter and total $\mathrm{N}$ was observed highest in zero tillage under wheat-mungbean $T$. aman cropping system. In most of the cases, $\mathrm{P}, \mathrm{K}, \mathrm{S}, \mathrm{Ca}, \mathrm{Mg}, \mathrm{Zn}$ and $\mathrm{B}$ contents were showed significanly higher in zero tillage $\left(\mathrm{T}_{1}\right)$. Zero tillage might be favoured to the soil microbial activities and biological properties improvement; those are ultimately increased soil fertility. Busari et al. (2015) noted similar statement. Ismail et al. (1994) and Rahman et al. (2008) reported that exchangeable $\mathrm{Ca}, \mathrm{Mg}$, and $\mathrm{K}$, were significantly higher in the surface soil under NT (no-tillage) compared to the ploughed soil.

Table 8. Effect of different tillage practices on postharvest soil $\mathrm{pH}$ and the status of different nutrients (mean of two years) with reference to initial soil

\begin{tabular}{|c|c|c|c|c|c|c|c|c|c|c|}
\hline Treatment & $\mathrm{pH}$ & $\mathrm{OC}$ & Total $\mathrm{N}$ & $\mathrm{Ca}$ & $\mathrm{Mg}$ & $\mathrm{K}$ & $\mathrm{P}$ & $\mathrm{S}$ & $\mathrm{Zn}$ & $\mathrm{B}$ \\
\hline & & \multicolumn{2}{|c|}{------- $\mathrm{g} \mathrm{kg}^{-1}$------ } & \multicolumn{3}{|c|}{------- meq. $100 \mathrm{~g}^{-1}$} & \multicolumn{4}{|c|}{----- } \\
\hline Initial & 7.4 & 8.38 & 0.65 & 13.1 & 5.15 & 0.16 & 16.0 & 18.3 & 1.10 & 0.16 \\
\hline $\mathrm{T}_{1}$ (Zero tillage) & $7.2 \mathrm{~b}$ & $8.90 \mathrm{a}$ & $0.75 \mathrm{a}$ & $12.9 \mathrm{a}$ & $5.10 \mathrm{a}$ & $0.16 \mathrm{a}$ & $16.5 \mathrm{a}$ & $18.6 \mathrm{a}$ & $1.17 \mathrm{a}$ & $0.18 \mathrm{a}$ \\
\hline $\mathrm{T}_{2}$ (Single tillage) & $7.3 \mathrm{a}$ & $8.61 \mathrm{c}$ & $0.70 \mathrm{~d}$ & $12.8 \mathrm{a}$ & $5.03 b$ & $0.14 \mathrm{c}$ & $16.4 \mathrm{ab}$ & $18.5 \mathrm{ab}$ & $1.16 \mathrm{ab}$ & $0.17 \mathrm{~b}$ \\
\hline $\mathrm{T}_{3}$ (Two tillage) & $7.3 \mathrm{a}$ & $8.67 \mathrm{bc}$ & $0.71 \mathrm{~cd}$ & $12.6 \mathrm{~b}$ & $5.00 \mathrm{c}$ & $0.14 \mathrm{c}$ & $16.4 \mathrm{ab}$ & $18.4 \mathrm{~b}$ & $1.15 b$ & $0.16 \mathrm{c}$ \\
\hline $\mathrm{T}_{4}$ (Three tillage) & $7.3 \mathrm{a}$ & $8.73 b$ & $0.72 b c$ & $12.4 \mathrm{c}$ & $4.92 \mathrm{e}$ & $0.14 \mathrm{c}$ & $16.4 \mathrm{ab}$ & $18.4 b$ & $1.15 \mathrm{~b}$ & $0.16 \mathrm{c}$ \\
\hline $\mathrm{T}_{5}$ (Four tillage) & $7.2 \mathrm{~b}$ & $8.84 \mathrm{a}$ & $0.73 b$ & $12.1 \mathrm{~d}$ & $4.96 \mathrm{~d}$ & $0.15 b$ & $16.3 b$ & $18.5 \mathrm{ab}$ & $1.16 \mathrm{ab}$ & $0.17 \mathrm{~b}$ \\
\hline CV $(\%)$ & 0.08 & 0.59 & 1.24 & 0.71 & 0.18 & 0.61 & 0.55 & 0.48 & 0.86 & 0.53 \\
\hline
\end{tabular}

Note. Values within the same column with a common letter do not differ significantly $(\mathrm{P} \leq 0.05)$.

\subsection{Economic Analysis}

Different tillage practices contributed to make variation in the cost of cultivation, gross return, gross margin and benefit cost ratio (Table 9). The highest cost of cultivation (Tk. $41082 \mathrm{ha}^{-1}$ ) was incurred in treatment $\mathrm{T}_{5}$ followed by treatments $\mathrm{T}_{4}, \mathrm{~T}_{3}$ and $\mathrm{T}_{2}$. However the lowest $\left(\mathrm{Tk} .35482 \mathrm{ha}^{-1}\right)$ cultivation cost was incurred in zero tillage $\left(\mathrm{T}_{1}\right)$ practice. The present experiment is also indicated that zero tillage practice might be cost effective since it saved production cost by $3.8 \%, 7.3 \%, 10.6 \%$ and $13.7 \%$ compared to single tillage $\left(\mathrm{T}_{2}\right)$, two tillages $\left(\mathrm{T}_{3}\right)$, three tillages $\left(\mathrm{T}_{4}\right)$ and four tillages $\left(\mathrm{T}_{5}\right)$, respectively. In this experiment, the maximum gross return (Tk. $\left.83700 \mathrm{ha}^{-1}\right)$ and gross margin (Tk. $48218 \mathrm{ha}^{-1}$ ) were noted from $\mathrm{T}_{1}$ treatment followed by $\mathrm{T}_{5}, \mathrm{~T}_{4}$ and $\mathrm{T}_{3}$. The minimum gross return (Tk. $\left.54360 \mathrm{ha}^{-1}\right)$ and gross margin $\left(\mathrm{Tk} .17478 \mathrm{ha}^{-1}\right)$ was recorded in one-tillage $\left(\mathrm{T}_{2}\right)$ treatment due to lower yield of chickpea. Similarly, the highest benefit cost ratio (BCR) 2.36 was counted from $T_{1}$ followed by $T_{5}$ and $T_{4}$ treatment and the lowest BCR (1.47) was from one-tillage $\left(\mathrm{T}_{2}\right)$ treatment (Table 9). Similar results were observed by Banjara et al. (2017) in chickpea that recorded the highest BCR (2.96) in zero tillage. Prasad et al. (2002) reported that during the two-year of study, zero tillage with the yields of 46.88 and $35.27 \mathrm{q} \mathrm{ha}^{-1}$ out yielded as compared to conventional tillage with the yield of 37.18 and $30.75 \mathrm{q} \mathrm{ha}^{-1}$ with markedly better net returns, benefit cost ratio and advancing sowing by 20 days.

Table 9. Effect of different tillage practices on the profitability of chickpea cultivation (Pooled data of two years)

\begin{tabular}{|c|c|c|c|c|c|}
\hline Treatment & Seed yield & Gross return & Variable cost & Gross margin & $\mathrm{BCR}$ \\
\hline & $\mathrm{kg} \mathrm{ha}^{-1}$ & ---------------- & Tk. ha ${ }^{-1}$ & ( & \\
\hline $\mathrm{T}_{1}$ (Zero tillage) & 1395 & 83700 & 35482 & 48218 & 2.36 \\
\hline $\mathrm{T}_{2}$ (Single tillage) & 906 & 54360 & 36882 & 17478 & 1.47 \\
\hline $\mathrm{T}_{3}$ (Two tillage) & 1087 & 65220 & 38282 & 26938 & 1.70 \\
\hline $\mathrm{T}_{4}$ (Three tillage) & 1152 & 69120 & 39682 & 29438 & 1.74 \\
\hline $\mathrm{T}_{5}$ (Four tillage) & 1247 & 74820 & 41082 & 33738 & 1.82 \\
\hline
\end{tabular}

Note. Input prices: Urea $=$ Tk. $16 \mathrm{~kg}^{-1}$, T.S.P. $=$ Tk. $22 \mathrm{~kg}^{-1}, \mathrm{MoP}=$ Tk. $17 \mathrm{~kg}^{-1}$, Gypsum $=$ Tk. $12 \mathrm{~kg}^{-1}, \mathrm{Zinc}$ sulphate $=$ Tk. $160 \mathrm{~kg}^{-1}$, Boric acid $=$ Tk. $155 \mathrm{~kg}^{-1}$, Secure $600 \mathrm{wg}=\mathrm{Tk} .200100^{-\mathrm{g}}$, Karate $=$ Tk. $450500^{-\mathrm{ml}}$, Chickpea seed $=$ Tk. $80 \mathrm{~kg}^{-1}$, Plowing $=$ Tk. $1400 \mathrm{ha}^{-1}$ (one pass), Wage rate $=$ Tk. 300 day $^{-1}$. Output price: Chickpea seed at TK. $60 \mathrm{~kg}^{-1}$.

\section{Summary and Conclusions}

The experiment has generated significant information on tillage practices to upscale the unit yield of chickpea and rising coverage of its cultivation. The tillage experiment indicates appreciably that zero tillage contributes to 
attain more branches and setting more pods per plant which finally augments the seed yield. Results reveal that the highest seed yield of chickpea $\left(1395 \mathrm{~kg} \mathrm{ha}^{-1}\right)$ has been achieved in zero tillage followed by the practice of four tillages $\left(T_{5}\right)$. Harvest index is also highest in zero tillage $\left(T_{1}\right)$. In this experiment, zero tillage practice has an effective tendency to obtain the maximum number of nodules per plant. Nutrient content shows non-significant effect across most of the treatments.The highest nutrient (N, P, K and $\mathrm{S}$ ) uptake also obtains from $\mathrm{T}_{1}$ treatment.The soil fertility is positively improved due to zero tillage followed by four tillages. The highest soil organic carbon, total $\mathrm{N}$, available $\mathrm{P}, \mathrm{S}, \mathrm{Ca}, \mathrm{Mg}, \mathrm{Zn}$ and $\mathrm{B}$ are recorded in zero tillage $\left(\mathrm{T}_{1}\right)$. The organic carbon, total N, available $\mathrm{P}, \mathrm{S}, \mathrm{Zn}$ and $\mathrm{B}$ content in postharvest soils of all tillage practices are higher than the initial soil except $\mathrm{K}, \mathrm{Ca}$ and $\mathrm{Mg}$ content. The zero tillage practice is more profitable than that of other tillage practices. Farmers can save ploughing cost ranged from $3.8 \%$ to $13.7 \%$ and time (minimum 8 days) by practicing zero tillage for succeeding crops. So, the present study suggests that zero tillage practice could be implemented in the high and medium high land for chickpea production. Future research may be carried out to evaluate the suitable rate of nutrients in zero tillage (conservative tillage) practice for yield maximization of chickpea and sustaining soil fertility.

\section{Reference}

Alam, M. K. (2018). Assessment of soil carbon sequestration and climate change mitigation potential under conservation agriculture practices in the Eastern Gangetic Plains ( $\mathrm{PhD}$ thesis, Murdoch University).

Alam, M. K., Islam, M. M., Salahin, N., \& Hasanuzzaman, M. (2014). Effect of Tillage Practices on Soil Properties and Crop Productivity in Wheat-Mungbean-Rice Cropping System under Subtropical Climatic Conditions. The Scientific World Journal, 2014, Article ID 437283. https://doi.org/10.1155/2014/437283

Alam, M. K., Salahin, N., Islam, S., Begum, R. A., Hasanuzzaman, M., Islam, M. S., \& Rahman, M. M. (2016). Patterns of change in soil organic matter, physical properties and crop productivity under tillage practices and cropping systems in Bangladesh. The Journal of Agricultural Science, 155, 216-238. https://doi.org/ $10.1017 / \mathrm{S} 0021859616000265$

Allmaras, R. R., Rickman, R. W., Ekin, L. G., \& Kimball, B. A. (1977). Chiselling influences on soil hydraulic properties. Soil Science Society of American Journal, 41(4), 796-803. https://doi.org/10.2136/sssaj1977. 03615995004100040039x

Aziz, I., Mahmood, T., \& Islam, K. R. (2013). Effect of long term no-till and conventional tillage practices on soil quality. Soil and Tillage Research, 131, 28-35. https://doi.org/10.1016/j.still.2013.03.002

Bandyopadhyay, P. K. (2012). Mitigating abiotic stresses and enhancing resource use efficiency in pulses in rice fallows through innovative resource conservation practices. Progress report on NFBSFARA project. ICAR Research Complex, Umium, Meghalaya.

Bangladesh Agricultural Research Council. (2012). Fertilizer Recommendation Guide (pp. 1-274). Bangladesh Agricultural Research Council, Dhaka, Bangladesh.

Banjara, T. R., Pali, G. P., Tigga, B. K., Kumar, S., \& Shori, A. (2017). Effect of Different Tillage Practices on Growth, Yield and Economics of Chickpea (Cicer arietinum L.) under Rainfed Condition of Chhattisgarh. International Journal of Current Microbiology and Applied Sciences, 6(2), 1464-1470. https://doi.org/ 10.20546/ijcmas.2017.602.164

Banjara, T. R., Pali, G. P., Tigga, B. K., Kumar, S., \& Shori, A. (2017). Effect of Different Tillage Practices on Growth, Yield and Economics of Chickpea (Cicer arietinum L.) under Rainfed Condition of Chhattisgarh. International Journal of Current Microbiology and Applied Sciences, 6(2), 1464-1470. https://doi.org/ 10.20546/ijcmas.2017.602.164

BBS (Bangladesh Bureau of Statistics). (2016). Yearbook of Agricultural Statistics of Bangladesh-2015. Bangladesh Bureau of statistics (p. 138). Statistics and informatics Division, Ministry of Planning, Government of the People's Republic of Bangladesh, Dhaka, Bangladesh.

Bell, R. W., Haque, M. E., Jahiruddin, M., Rahman, M. M., Begum, M., Miah, M. A. M., .. Mahmud, M. N. H. (2019). Conservation agriculture for rice-based intensive cropping by smallholders in the Eastern Gangetic Plain. Agriculture, 9(5), 1-17. https://doi.org/10.3390/agriculture9010005

Benjamin, J. G. (1993). Tillage effects on near-surface soil hydraulic properties. Soil and Tillage Research, 26(4), 277-288. https://doi.org/10.1016/0167-1987(93)90001-6

Bhattacharryya, R., Kundu, S., Pandey, S. C., Singh, K. P., \& Gupta, H. S. (2008). Tillage and irrigation effects on crop yields and soil properties under the rice-wheat system in the Indian Himalayas. Agricultural Water Management, 95(9), 993-1002. https://doi.org/10.1016/j.agwat.2008.03.007 
Bimbraw, A. S. (2016). Use of Conservation Technology for the Improvement in Production of Chickpea in Comparison to Wheat. Current Agriculture Research Journal, 4(1), 1-15. https://doi.org/10.12944/ CARJ.4.1.01

Black, C. A. (1965). Methods of Soil Analysis (Part I, Agron. Monograph. 9). ASA Madison, USA.

Bouyoucos, G. J. (1962). Hydrometer method improved for making particle size analysis of soils. Agronomy Journal, 54(5), 464-465. https://doi.org/10.2134/agronj1962.00021962005400050028x

Bremner, J. M., \& Mulvaney, C. S. (1982). Total nitrogen. In A. L. Page, R. H. Miller, \& D. R. Keeney (Eds.), Methods of Soil Analysis (Part 2, 2nd ed., pp. 599-622). American Society of Agronomy, Madison, USA.

Busari, M. A., \& Salako, F. K. (2013). Effect of tillage, poultry manure and NPK fertilizer on soil chemical properties and maize yield on an Alfisol at Abeokuta, south-western Nigeria. Nigerian Journal of Soil Science, 23(2), 206-218.

Busari, M. A., Singh Kukal, S., Kaur, A., Bhatt, R., \& Dulazi, A. A. (2015). Conservation tillage impacts on soil, crop and the environment. International Soil and Water Conservation Research, 3(2), 119-129. https://doi.org/10.1016/j.iswcr.2015.05.002

Corsi, S., Friedrich, T., Kassam, A., Pisante, M., \& de Moraes Sà, J. C. (2012). Soil organic carbon accumulation and greenhouse gas emission reductions from conservation agriculture: A literature review. Integrated Crop Management (Vol. 16, p. 101). Rome: AGP/FAO.

FAO. (2001). Conservation Agriculture, Matching Production with Sustainability. What is the Goal of Conservation Agriculture? FAO, Rome.

FAO. (2012). Advancement and impact of conservation agriculture/no-till technology adoption in Kazakhstan. FAO Information Note. Retrieved from http://www.fao.org/ag/ca/doc/Importance_Zero_Tillage_Northern_ Kazakhstan.pdf

Hargrove, W. L. (1985). Influence of Tillage on Nutrient Uptake and Yield of Corn. Agronomy Journal, 77, 763-768. https://doi.org/10.2134/agronj1985.00021962007700050022x

Hassan, A. E., Kitamura, Y., Ahmed, E. S., Samir, G., \& Irshad, M. (2005). Effect of irrigation schedules and tillage systems on rice productivity and soil physical characteristics-A case study in the north Nile Delta, Egypt. Proceedings of the 19th International Congress on Irrigation and Drainage, Beijing, China, September 2005.

Huq, S. M. I., \& Shoaib, J. U. M. (2013). The Soils of Bangladesh (World Soils Book Series 1). Springer Science. https://doi.org/10.1007/978-94-007-1128-0

Ismail, L., Blevins, R. L., \& Frye, W. W. (1994). Long-term no-tillage effects on soil properties and continuous corn yields. Soil Science Society of America Journal, 58, 193-198. https://doi.org/10.2136/sssaj1994.03615 995005800010028x

Johansen, C., Haque, M. E., Bell, R. W., Thierfelder, C., \& Esdaile, R. J. (2012). Conservation agriculture for small holder rain-fed farming: Opportunities and constraints of new mechanized seeding systems. Field Crops Research, 132, 18-32. https://doi.org/10.1016/j.fcr.2011.11.026

Katra, I. (2020). Soil Erosion by Wind and Dust Emission in Semi-Arid Soils Due to Agricultural Activities. Agronomy, 10(89), 1-10. https://doi.org/10.3390/agronomy10010089

Klute, A. (1965). Laboratory measurement of hydraulic conductivity of saturated soil. In C. A. Black (Ed.), Methods of Soil Analysis (Part I, pp. 210-220). American Society of Agronomy, Madison, Wisconsin, USA.

Lal, R. (1997). Long-term tillage and maize monoculture effects on at ropical Alfisol in western Nigeria .I. Crop yield and soil physical properties. Soil and Tillage Research, 42(3), 161-174. https://doi.org/10.1016/ S0167-1987(97)00007-X

Legesse H., Bunyamin, T., Walelign, W., \& Hussein, M. (2017). Towards zinc biofortification in chickpea: performance of chickpea cultivars in response to soil zinc application. Agronomy, 7(11), 1-14. https://doi.org/10.3390/agronomy7010011

Lindsay, W. L., \& Norvell, W. A. (1978). Development of DTPA soil test for zinc, iron, manganese and copper. Soil Science Society of American Journal, 42, 421-428. https://doi.org/10.2136/sssaj1978.0361599500420 0030009x

Monneveux, P., Quillerou, E., Sanchez, C., \& Lopez-Cesati, J. (2006). Effect of Zero Tillage and Residues Conservation on Continuous Maize Cropping in a Subtropical Environment (Mexico). Plant and Soil, 279, 95-105. https://doi.org/10.1007/s11104-005-0436-3 
Nazeer, S., Malik, A. U., Nazir, G., \& Ahmad, J. (2012). Effectiveness of tillage systems and farm manure levels on rice productivity. The Journal of Animal \& Plant Sciences, 22(2), 334-338.

Page, A. L., Miller, R. H., \& Keeney, D. R. (1982). Agronomy Series 9 ASA, SSSA. Methods of Soil Analysis (Part 2, 2nd ed., pp. 403-427). American Society of Agronomy, Madison, USA.

Peigné, J., Ball, B. C., Roger-Estrade, J., \& David, C. (2007). Is conservation tillage suitable for organic farming? A review. Soil Use and Mgmt., 23, 129-144. https://doi.org/10.1111/j.1475-2743.2006.00082.x

Piper, C. S. (1964). Soil and Plant Analysis. Adelaide University Press, Australia.

Poonia, T. C., \& Pithia, M. S. (2013). Pre- and post-emergence herbicides for weed management in chickpea. Indian Journal of Weed Science, 45(3), 223-225.

Prasad, B., Sinha, R. K., \& Singh, A. K. (2002). Studies on effect of nitrogen management on yield of wheat in rice-wheat cropping system under zero tillage. Proc Int. Symp. on Herbicide Resistance Management and Zero Tillage in Rice-Wheat Cropping System, March 4-6 at CCS HAU, Hisar, India (pp. 120-122).

Rahman, M. H., Okubo, A., Sugiyama, S., \& Mayland, H. F. (2008). Physical, chemical and microbiological properties of an Andisol as related to land use and tillage practice. Soil and Tillage Research, 101(1-2), 10-19. https://doi.org/10.1016/j.still.2008.05.006

Roy, R., Singh, A., \& Kang, J. S. (2014). Yield and quality of chickpea (Cicer arietinum) varieties as influenced by different planting techniques. Legume Research, 37(3), 294-299. https://doi.org/10.5958/j.0976-0571. 37.3.044

Salahin, N. (2017). Influence of minimum tillage and crop residue retention on soil organic matter, nutrient content and crop productivity in the rice-jute system (p. 246, PhD. Thesis, Department of Soil Science, Bangladesh Agricultural University, Mymensingh, Bangladesh).

Salahin, N., Alam, M. K., Shil, N. C., Mondol, A. T. M. A. I., \& Alam, M. J. (2019). Effects of tillage practices and nutrient management on crop productivity and profitability in jute- $T$. Aman rice-onion cropping system. Bangladesh Journal of Agricultural Research, 44(3), 387-399. https://doi.org/10.3329/bjar.v44i3.43473

Salehi, S., Rokhzadi, A., Abdolahi, A., Mohammadi, K., \& Nourmohammadi, G. (2017). Effect of soil tillage systems on chickpea yield and moisture of soil. Biosci. Biotech. Res. Comm., 10(3), 404-409. https://doi.org/10.21786/bbrc/10.3/11

Sharratt, B., Wendling, L., \& Feng, G. (2010). Windblown dust affected by tillage intensity during summer fallow. Aeolian Research, 2, 129-134. https://doi.org/10.1016/j.aeolia.2010.03.003

Singh, P., Sharratt, B., \& Schillinger, W. F. (2012). Wind erosion PM10 emission affected by tillage system in the world's driest rainfed wheat region. Soil and Tillage Research, 124, 219-225. https://doi.org/10.1016/ j.still.2012.06.009

Statistix 10. (1985). An Analytical Software. Tallahassee, FL.

Stewart, B., Fares Asfary, A., Belloum, A., Steiner, K., \& Friedrich, T. (2007). The proceedings of the international workshop on conservation agriculture for sustainable land management to improve the livelihood of people in dry areas, 7-9 May 2007, ACSAD \& GTZ, Damascus, Syria (p. 288).

Thomas, G. W. (1982). Exchangeable cations. In A. L. Page, et al. (Eds.), Methods of soil analysis: Part 2. Chemical and microbiological properties (ASA Monograph, Number 9, pp. 159-165).

Tithi, S. M., \& Barmon, B. K. (2018). Comparative advantages of lentil (Lens culinaris) and mustard (Brassica nigra L.) production and their profitability in a selected district of Bangladesh. The Agriculturists, 16(1), 21-33. https://doi.org/10.3329/agric.v16i1.37531

UNDP. (1988). Land resources appraisal of Bangladesh for agricultural development (Report 3, Vol. 1, pp. 33-48). Food and Agriculture Organization of the United Nations, Rome.

Vu, D. T., Tang, C., \& Armstrong, R. D. (2009). Tillage system affects phosphorus form and depth distribution in three contrasting Victorian soils. Australian Journal of Soil Research, 47(1), 33-45. https://oi.org/10.1071/ SR08108

\section{Copyrights}

Copyright for this article is retained by the author(s), with first publication rights granted to the journal.

This is an open-access article distributed under the terms and conditions of the Creative Commons Attribution license (http://creativecommons.org/licenses/by/4.0/). 